\title{
The Presence of Fibonacci Sequence in Malaysia Keris Design Related to Elements of Art and Principles of Design
}

\author{
Shahriman Zainal Abidin ${ }^{1,2}$, Rusmadiah Anwar ${ }^{1,2}$, Wan Nuraini Rahim ${ }^{1}$ \\ ${ }^{1}$ Faculty of Art \& Design, Universiti Teknologi MARA, 40450 Shah Alam, Selangor Malaysia \\ ${ }^{2}$ Formgiving Design Research Group, Universiti Teknologi MARA, 40450 Shah Alam, Selangor Malaysia \\ shahriman.z.a@uitm.edu.my; rusma935@uitm.edu.my; wannuraini@gmail.com \\ Tel: +60193512965
}

\begin{abstract}
This paper discusses the Malaysia Keris design within the scope of the presence of the Fibonacci sequence component in design related to the art elements and design principles, which make it stand as an iconic item to symbolise Malaysian identity. The existing literature emphasised on the philosophical part of it. Using tool or instrument, of form analysis based on Fibonacci sequence spiral, has mapped the DNA of the design. The empirical findings show that the existence of Fibonacci sequences is significant in Malaysian keris design. Moreover, 'emphasis' has given the distribution of the visual weight of objects and value.
\end{abstract}

Keywords: Elements of art; Fibonacci sequence; Keris; Principles of design

eISSN: 2398-42870 2020. The Authors. Published for AMER ABRA cE-Bsby e-International Publishing House, Ltd., UK. This is an open access article under the CC BYNC-ND license (http://creativecommons.org/licenses/by-nc-nd/4.0/). Peer-review under responsibility of AMER (Association of Malaysian Environment-Behaviour Researchers), ABRA (Association of Behavioural Researchers on Asians) and cE-Bs (Centre for Environment-Behaviour Studies), Faculty of Architecture, Planning \& Surveying, Universiti Teknologi MARA, Malaysia.

DOI: https://doi.org/10.21834/ebpj.v5iSl3.2547

\subsection{Introduction}

Keris is a weapon in Malaysia that has very influences in the heart of the Malay in their life as an identity represents the culture and heritage. It is also a status symbol for the owners to show their status in the communities. At the Royal Palace level, Keris exhibited the symbols of lavishness, the power and authority of the Malay rulers. Moreover, the Keris is often associated with the characters of the fearless and knowledgeable king (see Norman, Legino, Anwar \& Hassan, 2016). According to Ahmad (2015), for ordinary Malay people, Keris has its superstitious functions in Malay culture and design of Keris has always been pleasing. The design of Keris is not only artistic, but it is also practical for fighting. The curved edge created a wound that can cause critical damage to the internal organs. Therefore, it can be fatal. The hulu (handle) of the Keris is not only beautiful, but it is also ergonomics of the handgrip. Keris is the unification of Malay aesthetics skills and design intelligence. The integration of the functionality and beauty characteristics has created one of the most beautiful weapons ever existed in history.

At this point, there were no researchers related to the design of Keris with regards to the structure establishment and aesthetical form has been done for the Keris. Looking at the keris shape and form, it seems that the design is quite proportionate. Since Fibonacci sequence theory has measure most of the universal design (see Ali \& Liem, 2014), so that, in this research, we wanted to use the same model, to see whether the theory was presented in the design of Keris. Generally, the Fibonacci sequence is a mathematical ratio commonly found in nature with the ratio of 1 to 1.6 .18 that has many names (see Merriam-Webster, 2006). In most cases, it was

eISSN: 2398-4287C 2020. The Authors. Published for AMER ABRA cE-Bsby e-International Publishing House, Ltd., UK. This is an open access article under the CC BYNC-ND license (http://creativecommons.org/licenses/by-nc-nd/4.0/). Peer-review under responsibility of AMER (Association of Malaysian Environment-Behaviour Researchers), ABRA (Association of Behavioural Researchers on Asians) and cE-Bs (Centre for Environment-Behaviour Studies), Faculty of Architecture, Planning \& Surveying, Universiti Teknologi MARA, Malaysia.

DOI: https://doi.org/10.21834/ebpj.v5iSI3.2547 
called the Golden Section, Golden Ratio, or Golden Means. At the same times, it's also irregularly referred to as the Golden Number, Divine Proportion, Golden Proportion, Fibonacci Number, and Phi. A Golden ratio can be found as a square and another rectangle that formed a single large rectangle. What is unique about this is that the sequence can be repeated infinitely and perfectly with each section, which is similar to the studies of design DNA (see Abidin et al., 2017). These can be applied to the structures and design on Keris throughout all point to its universality. It's either the rectangles of the size of the width of the bilah (blade) on the Keris to the thin, narrow scale at the hujung or tuntung (tip) of the Keris. However, when discussing the aesthetics of the Keris, several issues seem to be praised. The questions here, 1) Can we use any tools or instruments to analyse the design DNA of the Keris? and 2) Can we measure the structure establishment of the Keris based on factors of the elements of art and principles of design?

\subsection{Methodology}

In this work, the inquiry research activities have been made (see Fig.1). Fifty numbers of samples have been selected for the study of form structure levels for the Malaysia Keris based on a heuristic evaluation of all elements, and ten numbers of samples have been selected for the study of form structure levels for the Malaysia Keris based on elements of art and principles of design. It is sufficient enough for the research based on qualitative inquiry (see Patton, 2002). The samples are a master's degree in Art \& Design students from the Universiti Teknologi MARA (UiTM), who taking EDT701 Practice-based Design Thinking, an elective subject. Six types of Malaysia Keris have been observed and analysed such as 1) Keris Pandai Saras, 2) Keris Alang Berlurah, 3) Keris Bugis Semenanjung, 4) Keris Melela, 5) Keris Tajong, and 6) Keris Sundang Lurus.

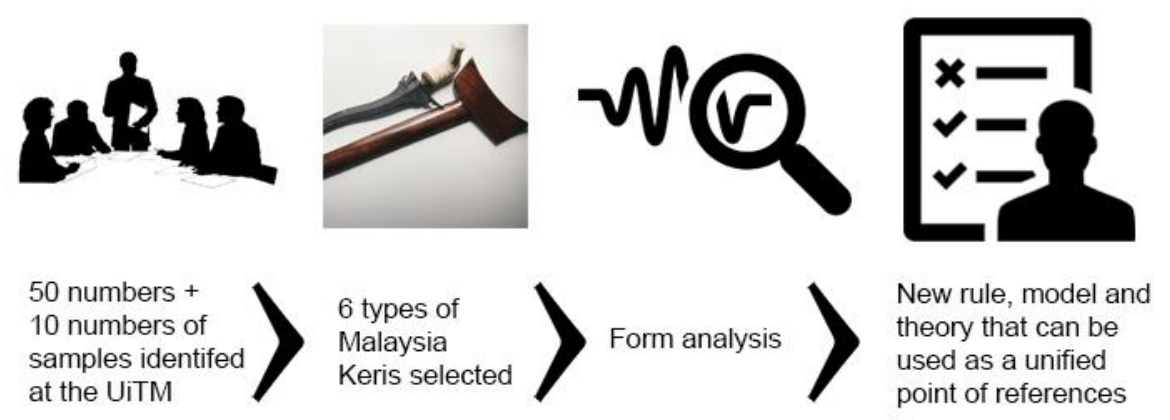

Fig.1: Schematic of the inquiry research activities

The Fibonacci sequence model has been used in the analysis, and it covers Keris form syntax (structure) or designs syntactic with regards to the product architecture only (see Warell, 2002). The coding was based on the selected items and rank of components based on the characteristics and properties of Keris such as hulu, pendokok, bilah or Mata Keris (puting, umbi, kendek, duri mengkuang, duri penyangga, ganja, kepak, bibir, akut, lidah, kerawang, lurah, alor, tulang tebing, pucuk, hujung or tuntung), and sarung (sampir, Batang serunai, tampuk) (see Table 1). In this context, the terms of the definition of Malaysia Keris components from Malay to English were based on Merriam-Webster's Collegiate Dictionary. All key term use in this paper was based on Malay linguistic interpretation.

Table 1: Terms of definition of the Malaysia Keris components

\begin{tabular}{|c|c|c|}
\hline No & Malay & Interpretation \\
\hline 1 & hulu & a part that is designed especially to be grasped by the hand \\
\hline 2 & pendokok & a royal or imperial headdress or cap of sovereignty \\
\hline 3 & bilah or mata Keris & the cutting part of an implement \\
\hline 4 & puting & a pipe coupling consisting of a short piece of threaded tubing \\
\hline 5 & umbi & a fleshy root or rhizome resembling a tuber \\
\hline 6 & kendek & a square of cloth used as a head covering or worn as a scarf around the neck \\
\hline 7 & duri mengkuang & any of various sharp spinose structures based on mengkuang items or properties \\
\hline 8 & duri penyangga & any of various sharp spinose structures based on penyangga items or properties \\
\hline 9 & ganja & an obnoxious growth or thing \\
\hline 10 & kepak & $\begin{array}{l}\text { one of the movable feathered or membranous paired appendages by means of which a } \\
\text { bird, bat, or insect is able to fly }\end{array}$ \\
\hline 11 & bibir & a projecting edge \\
\hline 12 & akut & spiral or winding around a center or pole and gradually receding from or approaching it \\
\hline 13 & lidah & $\begin{array}{l}\text { a fleshy movable muscular process of the floor of the mouths of most vertebrates that } \\
\text { bears sensory end organs and small glands and functions especially in taking and } \\
\text { swallowing food and in humans as a speech organ }\end{array}$ \\
\hline 14 & kerawang & something that lends grace or beauty \\
\hline 15 & lurah & bent or formed into a curve \\
\hline 16 & alor & a long narrow channel \\
\hline 17 & tulang & one of the hard parts of the skeleton of a vertebrate \\
\hline 18 & tebing & a very steep, vertical, or overhanging face of rock or earth \\
\hline
\end{tabular}




\begin{tabular}{|c|c|c|}
\hline 19 & pucuk & $\begin{array}{l}\text { an upright architectural member generally ending in a small spire and used especially in } \\
\text { Gothic construction to give weight especially to a buttress }\end{array}$ \\
\hline 20 & hujung or tuntung & the part of an area that lies at the boundary \\
\hline 21 & sarung & $\begin{array}{l}\text { a loose garment made of a long strip of cloth wrapped around the body that is worn by } \\
\text { men and women chiefly of the Malay Archipelago and the Pacific islands }\end{array}$ \\
\hline 22 & sampir & a large seagoing vessel \\
\hline 23 & batang serunai & a woody piece or part of a tree or shrub based on Serunai items or properties \\
\hline 24 & tampuk & a cup-shaped animal structure \\
\hline
\end{tabular}

The terms of Malaysia Keris anatomy or parts with regards to items and components were coined by Mohd Noordin Abd Hamid, Keris maker and keris subject matter expert (see Fig.2). The uncertainty elements revealed from the study has been used to confirm the findings. Moreover, the analysis of form structure level of Malaysia Keris based on elements of arts and principles of design have been carried out. For elements of art, it covers line, shape, form texture, space, colour and value (see Akner-Koler, 2000). Meanwhile, for the principles of design, it covers unity, balance, emphasis, movement, contra, rhythm and pattern (see Muller, 2001).
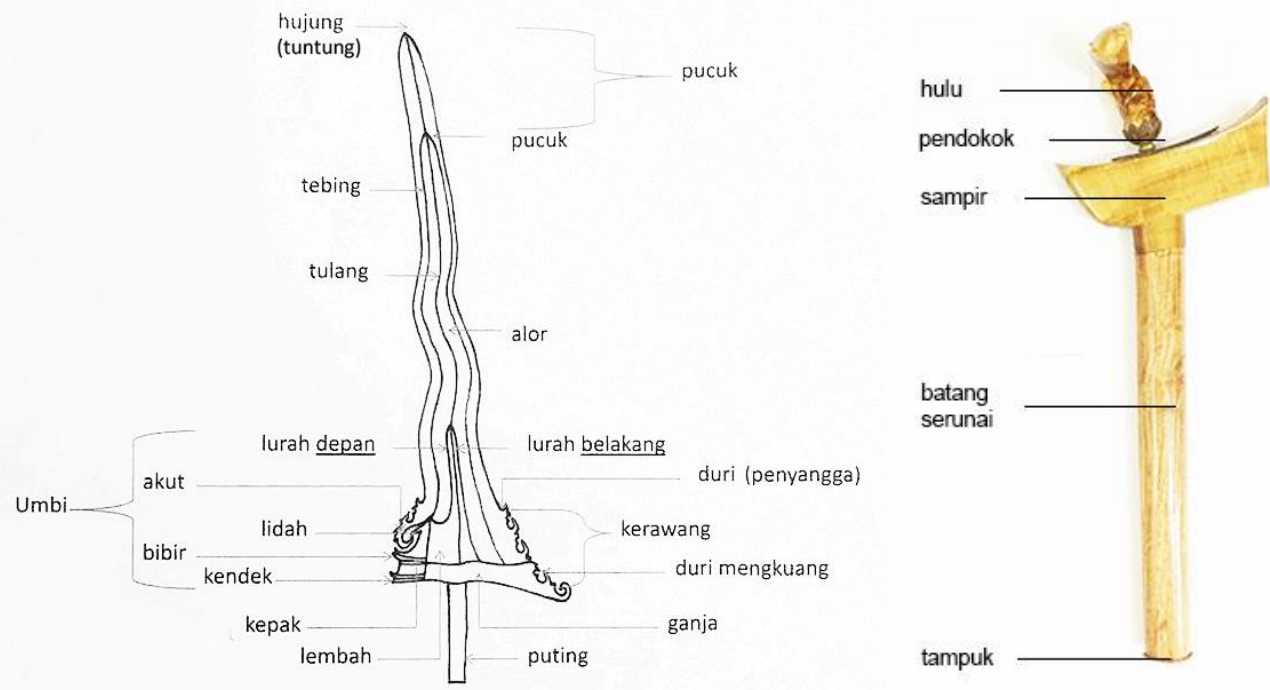

Fig.2: Malaysia Keris anatomy (Source: Mohd Noordin Abd Hamid, 2018)

\subsection{Results \& Discussion}

Results for study indicates that the subjects are very subjective, private and selective in determining which part of Malaysia Keris reflect subjects own preferences. It can be seen through three examples of analysis that have been conducted. The explanation about the present of Fibonacci Sequence through analysis of form structure levels for the Malaysia Keris based on a heuristic evaluation of all elements indicated by subjects and analysis of form structure levels for the Malaysia keris based on elements of art and principles of design indicated by subjects have confirmed the findings.

\section{Can we use any tools or instruments to analyse the design DNA of the keris?}

A finding from the inquiry research activities indicates the use of a tool or instrument to analyse the DNA of the Keris design can reveal something interesting. After analysing form structure levels for the Malaysia keris based on a heuristic evaluation of all elements indicated by subjects. It shows that the 50 subjects reflect on the reference with regards to the permanent features of Malaysia Keris selectively. As can be seen in Table 2, at all 6 Keris, after combining the frequencies number, the most significant areas of the Keris are hulu (159), pendokok (10), bilah or Mata Keris (41), umbi (85), kendek (14), duri mengkuang (43), duri penyangga (36), ganja (32), akut (65), kerawang (47), lurah (3), alor (10), tulang (3), tebing (17), hujung @ tuntung (6), sarung (27), sampir (83), Batang serunai (27), and tampuk (19). The hulu indicate the most popular component or item in the eye of the subjects. We can see that the hulu illustrate the same character that we can also find in nature, even on the hand of a person. Therefore, when the handle applied the Fibonacci sequence component, the side that grip or hold the Keris handles can fit with it.

The Fibonacci sequence spiral component matches at several areas of Keris design. It can be seen in all of its primary parts which are the hulu, bilah and sarung. For instance, hulu looks obvious when it has been included with the pendokok. Bilah consists of akut, lidah, kerawang, alor, lurah, tulang, tebing, duri mengkuang and duri penyangga. The sarung comes together with a complete set of sampir, batang serunai and tampuk. The shape of ' $L$ ' in keris design indicates that the ratio 8 is at the hulu, which given good grip of the palm. The $L$ shape of the hulu provides the user with ease to stab from the front while the bilah help it to move fast. The bilah seems unbalanced, however, the ratio still following the golden ratio, as can be seen, the bilah ratio eight until 5 has the ticker and rounder bilah, and bilah from ratio 3 to 1 has the thicker bilah up to the hujung or tuntung. The volume rationed the bilah. The mechanism of the bilah can cause a fatal injury because of the hujung or tuntung with ratio 1, are thin and sharp to pierce on the 
human body while the ratio five until 8 of the bilah is round and thick to hurt the stabbed part. That means, the Keris stabs the human body, the wound is not sliced, but it leaves a hole that punched the body part of the enemy.

All of the Keris covers also functioned to fight, and defence as the base shaped like an axe used to pound the enemy while the sarung can be used to break the enemy's neck, while the tampuk of the sarung used to jab the enemy while fighting or defending. The application of the Fibonacci sequence on it fit with the bilah gives practicality to Keris design. This is important for ergonomic design. Ergonomic design is all about form and function of the Keris design. Designers use the principles of ergonomics in every aspect of Keris design. In any ergonomic design, the design should accommodate for the flow variations, for people and designers (see Grandjean, Kroemer, \& Kroemer, 1997). It can be in the form of cognitive and physical ergonomic towards design. A successful Keris design perfectly regulates base circulation and accommodates enough space according to the requirement of quantity. In Keris design, when the designer is thinking of ergonomic design, it shows that they have thought about designing for efficiency. Aesthetically, the design of the product is about pleasing peoples' awareness (Crilly, 2005). The design should use the correct balance of proportion, lighting and style, optimise a pleasing aesthetic for the owner. We can see that the design of Keris does not go overboard; this sense may create an unpleasant, uncomfortable and cluttered aesthetic. Hence, we can see in the design of Malaysia Keris; designer tries to avoid confusion in planning by understanding the need for adjusting capabilities and the incorporate solutions into the design. To avoid this, it shows designer choosing the right Keris form structure and materials, think about the tones, finishes and textures and try to choose samples that complement each other.

Table 2: Analysis of form structure levels for the Malaysia Keris based on a heuristic evaluation of all elements indicated by subjects

\begin{tabular}{|c|c|c|c|}
\hline No & Type & Matches with Fibonacci sequence spiral & Consistencies \\
\hline 1 & Keris Pandai Saras & & $\begin{array}{l}\text { hulu (28), } \\
\text { pendokok (5), } \\
\text { bilah or mata Keris (9) such as: puting (0), umbi (18), } \\
\text { kendek (4), duri mengkuang (8), duri penyangga (6), ganja } \\
\text { (6), kepak (0), bibir (0), akut (11), lidah (0), kerawang (8), } \\
\text { lurah (0), alor (0), tulang (0), tebing (4), pucuk (0), hujung or } \\
\text { tuntung (4), } \\
\text { sarung (7) such as: sampir (14), batang serunai (7), tampuk } \\
\text { (7) }\end{array}$ \\
\hline 2 & $\begin{array}{ll}\text { Keris } & \text { Alang } \\
\text { Berlurah } & \end{array}$ & & $\begin{array}{l}\text { hulu (27), } \\
\text { pendokok (5), } \\
\text { bilah or mata Keris (18) such as: puting (0), umbi (18), } \\
\text { kendek (4), duri mengkuang (8), duri penyangga (8), ganja } \\
\text { (15), kepak (0), bibir (0), akut (5), lidah (0), kerawang (11), } \\
\text { lurah (0), alor (0), tulang (0), tebing (0), pucuk (0), hujung or } \\
\text { tuntung (0), } \\
\text { sarung (11) such as: sampir (22), batang serunai (11), } \\
\text { tampuk (9) }\end{array}$ \\
\hline 3 & $\begin{array}{l}\text { Keris Bugis } \\
\text { Semenanjung }\end{array}$ & & $\begin{array}{l}\text { hulu (29), } \\
\text { pendokok (2), } \\
\text { bilah or mata Keris (5) such as: puting (0), umbi (21), } \\
\text { kendek (3), duri mengkuang (14), duri penyangga (11), ganja } \\
\text { (11), kepak (0), bibir (0), akut (19), lidah (0), kerawang (12), } \\
\text { lurah (0), alor (0), tulang (0), tebing (10), pucuk (0), hujung or } \\
\text { tuntung (0), } \\
\text { sarung (2) such as: sampir (12), batang serunai (2), tampuk } \\
\text { (0) }\end{array}$ \\
\hline 4 & Keris Melela & & $\begin{array}{l}\text { hulu (5), } \\
\text { pendokok (0), } \\
\text { bilah or mata Keris (0) such as: puting (0), umbi (0), kendek } \\
\text { (0), duri mengkuang (0), duri penyangga (0), ganja (0), kepak } \\
\text { (0), bibir (0), akut (5), lidah (0), kerawang (0), lurah (0), alor } \\
\text { (0), tulang (0), tebing }(0) \text {, pucuk (0), hujung or tuntung (0), } \\
\text { sarung (0) such as: sampir }(0) \text {, batang serunai (0), tampuk } \\
\text { (0) }\end{array}$ \\
\hline
\end{tabular}




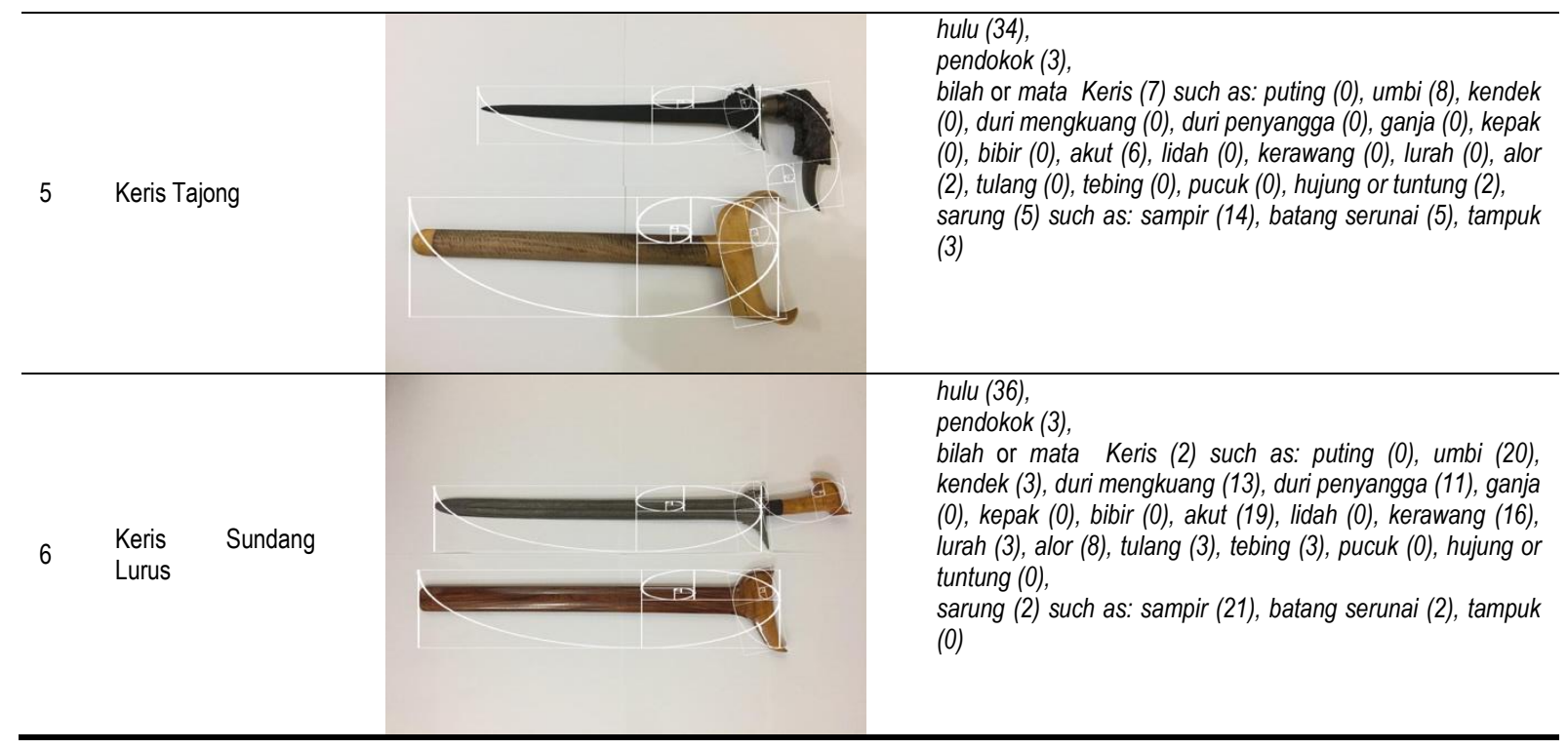

Can we measure the structure establishment of the Keris based on factors of elements of art and principles of design?

Since Malaysia Keris design matches with Fibonacci sequence component, the design looks well proportionate. The significance for the analysis of form structure levels for the Malaysia Keris based on elements of art (see Table 3) and principles of design (see Table 4) indicated by ten subjects' shows the consistencies. In this analysis, the rank of accepting is 'Yes' which is between 8 to 10. Meanwhile, for 'Maybe' the rank is between 1 to 7 . Looking at the findings of form structure levels for the Malaysia Keris based on elements of art indicated by subjects (see Table 2), the properties of Line, Shape, Form, and Value have given an impact of 'Yes' consistently in the eye of the subjects towards most of Malaysia Keris accept Keris Alang Berlurah with 'Maybe' in this study. However, the texture seems 'Maybe' for Keris Pandai Saras, Keris Alang Berlurah, keris Melela, Keris Tajong, and Keris Sundang Lurus accept Keris Bugis Semenanjung; and Space and Color seem 'Maybe' for Keris Pandai Saras, Keris Alang Berlurah, Keris Bugis Semenanjung, Keris Melela, Keris Tajong, and Keris Sundang Lurus. In the analysis of Malaysia Keris, the interpretation of properties can be defined as Line (contour lines, parallel lines, cross lines crossing, lines recording fast or gestural objects, implied lines and expressive lines); Shape (geometric and organic appearance, positive appearance and negative appearance, abstract appearance and appearance of outer lines); Form (geometric, organic, natural, realistic, abstract and non-obstructive forms; Texture (realties and impersonation, fabric, wood, iron and natural); Space (two-dimensional and three-dimensional space, with different dimensions and overlaps to perspectives); Color (prime and secondary colour, hot colour, cold colour, natural colour, colour value, dark colour brightness); and Value (high key painting value and low key, value contra, stage value, and quality and value contained in perspective).With that, it indicates 'emphasis' has given the distribution of the visual weight of objects and value. Moreover, if the design was a scale, these elements should be balanced to make a design feel stable. This is an agreement with Schön and Wiggins (1992) that seeing and their functions in designing are interrelated.

Table 3: Analysis of form structure levels for the Malaysia Keris based on elements of art

\begin{tabular}{|c|c|c|c|c|c|c|c|c|}
\hline No & Type & Line & Shape & Form & Texture & Space & Colour & Value \\
\hline 1 & Keris Pandai Saras & •(10) & $\bullet(10)$ & •(10) & $0(5)$ & $0(4)$ & $0(6)$ & • (8) \\
\hline 2 & Keris Alang Berlurah & •(10) & •(10) & •(10) & $0(5)$ & $0(2)$ & $0(3)$ & $0(7)$ \\
\hline 3 & Keris Bugis Semenanjung & •(10) & •(10) & •(10) & $\bullet(10)$ & $0(5)$ & $0(4)$ & - (8) \\
\hline 4 & Keris Melela & •(10) & •(10) & •(10) & $0(7)$ & $0(3)$ & $0(5)$ & •(9) \\
\hline 5 & Keris Tajong & •(10) & •(10) & - (9) & $0(5)$ & $0(3)$ & $0(4)$ & -(9) \\
\hline 6 & Keris Sundang Lurus & •(10) & •(10) & -(9) & $0(6)$ & $0(4)$ & $0(4)$ & - $(10)$ \\
\hline
\end{tabular}

In the analysis of form structure levels for the Malaysia Keris from the indication (based on principles of design) of the subjects (see Table 4), an item such as Emphasis has given an impact of 'Yes' consistently for all types of Malaysia Keris. Unity has received 'Yes' for Keris Tajong, and balance has received 'Yes' for Keris Pandai Saras and keris Sundang Lurus. The movement has received 'Yes' for Keris Pandai Saras, Keris Bugis Semenanjung and Keris Melela while Contra has received 'Yes' Keris Melela. At the same time, Rhythm has received 'Yes' for Keris Bugis Semenanjung. The pattern has received 'Yes' for Keris Pandai Saras, Keris Bugis Semenanjung, Keris Melela and Keris Tajong. Therefore, the other types of Keris have received 'Maybe' for the principles of design that can see in Table 4. In the analysis of Malaysia Keris, the interpretation of properties can define as [1] unity (colour, bravery, appearance and value are used to create something); [2] Balance (symmetrical and non-symmetric balance, the balance of balance and balance of value, appearance, colour and ties); [3] Emphasis (colour domination, focus area and visible emphasis and appearance); [4] Movement (movement of a flat or straight line, visible movement and appearance, value and perspective); [5] Contra (value of a conflict, colour of excitement, bravery, appearance, the colour of heat and cold contradiction); [6] Rhythm (stacked, 
unorganized and progressive rhythm, rhythm creation includes repeating colours, shapes and lines); and [7] Pattern (organized and random repetition covers colours, lines, values and links to create patterns).

With that, it indicates 'emphasis' has given the distribution of the visual weight of objects and value. Moreover, if the design was a scale, these elements should be balanced to make a design feel stable. This is an agreement with Schön and Wiggins (1992) that seeing and their functions in designing are interrelated.

Table 4: Analysis of form structure levels for the Malaysia Keris based on principles of design

\begin{tabular}{|c|c|c|c|c|c|c|c|c|}
\hline No & Type & Unity & Balance & Emphasis & Movement & Contra & Rhythm & Pattern \\
\hline 1 & Keris Pandai Saras & $0(5)$ & • (8) & - (8) & $\bullet(9)$ & $0(7)$ & $0(3)$ & $\bullet(8)$ \\
\hline 2 & Keris Alang Berlurah & o (6) & $0(7)$ & - (9) & $0(3)$ & $0(3)$ & $0(1)$ & $0(4)$ \\
\hline 3 & Keris Bugis Semenanjung & $0(6)$ & o (6) & - (9) & - (9) & $0(5)$ & - (8) & - (8) \\
\hline 4 & Keris Melela & o (5) & $0(7)$ & - (10) & • (10) & - (8) & $0(7)$ & • (10) \\
\hline 5 & Keris Tajong & • (8) & $0(6)$ & - (10) & $0(4)$ & $0(6)$ & $0(1)$ & - (10) \\
\hline 6 & Keris Sundang Lurus & o (7) & - (8) & - (9) & $0(4)$ & $0(7)$ & $0(2)$ & o (7) \\
\hline
\end{tabular}

\section{Conclusion}

In a nutshell, the presence of the Fibonacci sequence on the Malaysia Keris design is significant. It indicates that: 1) the tools or instruments to analyse the design DNA of the keris, and 2) measurement of the structure establishment of the Keris based on factors of the elements of art and principles of design can be developed. These studies confirm that the design of Malaysia Keris is not just the work of art which is deals with style and ornamentation. It is more than which deals with the visual appearance of the product. It is the way designer reasons and generates solutions from idea to detailed concept. Hence, we can see that the Keris maker is a product designer and its ability is equal to an inventor because the Keris maker seems to consider the Fibonacci sequence component in the design of Malaysia Keris. The elements of art and principles of design are important to reveal aesthetical features, stabilise form structure, and rationalise functional aspect with regards to ergonomic characteristics. Even, it shows the way Malay designer thinking about form-giving in design may include this component implicit. Furthermore, the way of Malay designer reasoning about Keris design can be a very structured approach (i.e., Problem-solving, Normative, Synthesis-analysis) and unstructured approaches (i.e., Reflective, Hermeneutic). Finally, it signifies the division of art and science blend well in the eye of the Malay designer. The Keris design was unique, and it consists of elements of art and principles of design. This makes design standing as universal design without neglected indigenous culture and heritage of the Malay segment about Malaysia item or characteristic as product design brand and identity.

\section{Acknowledgement}

The authors gratefully acknowledge the help of the Institute of Research Management \& Innovation (IRMI), Universiti Teknologi MARA in providing the Bestari Fund (Project Number: 600-IRMI/MYRA 5/3/BESTARI (042/2017)) research grant under the project title: Modeling Innovative Brand Identity Product Design Character Traits Based on Keris Syntactic Properties. The authors are also thankful to Mohd Noordin Abd Hamid, keris Maker and keris subject matter expert for providing at no charge the Malaysian Keris information that was used in this research.

\section{References}

Abidin, S. Z., Othman, A., Shamsuddin, Z., Samsudin, Z., Hassan, H., \& Mohamed, W. A. W. (2017). Identifying sequence maps or locus to represent the genetic structure or genome standard of styling DNA in automotive design. Lecture Notes in Mechanical Engineering, 1159-1166.

Ahmad, A. M. (2015). Keris Melayu Semenanjung: Suatu Pengenalan. Serdang: UPM Press.

Ali, A., \& Liem, A. (2014). The use of formal aesthetic principles as a tool for design conceptualisation and detailing, In Proceedings of NordDesign 2014 Conference (pp. 490-499).

Akner-Koler, C. (2000). Three-dimensional visual analysis. Stockholm: Reproprint.

Crilly, N. (2005). Product Aesthetics: representing designer intent and consumer response. Cambridge: University of Cambridge.

Grandjean, E., Kroemer, K., \& Kroemer, K. H. E. (1997). Fitting the Task to the Human. London: Taylor \& Francis.

Merriam-Webster (2006). Merriam-Webster's Collegiate Dictionary (11 th ed.). Massachusetts: Merriam-Webster, Incorporated.

Muller, W. (2001). Order and Meaning in Design. Utrecht: LEMMA Publishers.

Norman, N., Legino, R., Anwar, R., \& Hassan, O. H. (2016). Traditional keris Pandai Saras design. In International Colloquium of Art and Design Education Research (iCADER 2014) (pp. 17-24). Springer Singapore. 
Patton, M. Q. (2002). Qualitative Research \& Evaluation Methods (3rd ed.). Thousand Oaks, CA: Sage Publications, Inc.

Schön, D. A., \& Wiggins, G. (1992). Kind of seeing and their functions in designing. Design Studies, 16 (3), 135 - 156.

Warell, A. (2002). Design Syntactics: A Functional Approach to Visual Product Form - Theory, Models, and Methods. PhD Thesis. Gothenburg: Chalmers University of Technology. 